\title{
PROTECTION AGAINST DOMESTIC VIOLENCE IN THE MEANING OF THE FAMILY LAW AND THE LAW ON SOCIAL PROTECTION
}

\begin{abstract}
Domestic violence is a complex, multidisciplinary problem, although at first glance it seems like a very clear, definite, extremely obvious, and recognizable phenomenon. In addition to the concept, characteristics, manifestation, and causes of domestic violence, the paper presents the provisions of the Family Law and the Law on Social Protection, as well as the role and competencies of the Social Services Center regarding protection from domestic violence. The so-called "dark figure" in this area indicates that there is a significant number of unreported cases of domestic violence, and the "silence" of family members can lead to immeasurable consequences. That is why it is necessary to emphasize adequate education, good coordination of institutions, but also influencing the social awareness of people that denying the perceived problem of domestic violence leads nowhere.
\end{abstract}

Keywords: Domestic Violence, Family Law, Law on Social Protection, Social Services Center

\section{Introduction}

Domestic violence is a phenomenon that has become a very current subject of scholarly analysis in recent years, but at the same time, a behavior,

\footnotetext{
*PhD., Bankruptcy Trustee, Odžaci, Serbia, e-mail: stamenkovic223@gmail.com

(c) () (C) 2021 by the authors. This article is an open access article distributed under the terms and conditions of the Creative Commons Attribution (CC BY) license (https://creativecommons. org/licenses/by/4.0/).
} 
for the suppression of which the practice itself is particularly interested. Certainly, such tendencies were influenced by the development of the legal and institutional response, as well as the long-standing attitude that domestic violence is not only and exclusively a private family problem. In this regard, it is noted in theory that "domestic violence is a social phenomenon that affects both the lives of individuals and society as a whole" (Petrušić, Žunić \& Vilić, 2018, p. 7).

According to Nikolić Ristanović (2002), "research on the prevalence of domestic violence in our country shows that in a sample of 700 women, every third stated that they were a victim of some form of physical and every second - psychological violence in the family" (p. 13). Ipso facto, Domestic violence is considered a "long-lasting phenomenon", and models and patterns of its existence and prevalence are part of patriarchal or traditional understandings of gender norms, gender patterns, and family relations" (Petrušić et. al., 2018, p. 7). Ignjatović notes that the use of the term "domestic violence", as well as "violence in intimate partnerships", but also the newer term "gender-based violence" obscures their gender dimension and the fact that women are in a much higher percentage, in a specific way and with serious consequences, victims of this type of violence" (Ignjatović, 2011, pp. 13-14).

Domestic violence can be defined as one of the most severe forms of violence, because its manifestation violates basic human rights and freedoms of family members, such as the right to life, the right to liberty and security, physical, sexual and mental integrity, and dignity (Petrušić \& Konstantinović Vilić, 2010), and "occurs as a consequence of both power imbalances between individual family members, most often partners or ex-partners, and the tendency for this power imbalance to be exploited or abused by an individual to establish dominance and control over a partner or other family member who has less power in the relationship" (Žarković et al., 2012, p. 5). It is a "complex problem", for the understanding of which it is necessary to take into account the effect of several factors" (Opsenica Kostić, Todorović \& Janković, 2016, p. 133).

Available research indicates that "domestic violence has very serious social and individual consequences and that its victims are far more often women and children than adult men." (Konstatinović Vilić \& Petrušić, 2003, p. 27).

Domestic violence, at first glance, seems like a very clear, definite, extremely obvious, and recognizable problem (Dragojlović \& Matijašević Obradović, 2019, p. 56). However, we must not lose sight of the fact that more often than not, phenomena that seem simple, are very complex. Also, we should not ignore the fact that examples from practice can surpass even the most thorough theoretical claims and legal provisions. Accordingly, Njagulović (2012) points out 
that "good legal regulations are canceled by social reality daily, and the number of reported cases is increasing from year to year, but it does not reflect the true state of affairs, given that many violent behaviors never cross the family threshold" (p. 594). Additionally, it should be noted that there is no single view of the circle of behaviors that are considered violent.

The following text will discuss the concept, forms, and causes of domestic violence, and then the subject of analysis will be the provisions of the Family Law and the provisions of the Law on Social Protection, in the part concerning protection from domestic violence, where it is important to mention the role of the Social Services Center, in the part of the application of social protection measures in cases of domestic violence.

\section{The Concept, Forms and Causes of Domestic Violence}

As already mentioned, domestic violence is reported far less frequently than actual representation in practice. Patriarchal perceptions of family relationships, fear of revenge of the perpetrator, fear of condemnation of the social environment or friends, reasons of existential nature, are some of the reasons why victims rarely report this form of violence. The so-called "dark figure" in this area indicates that there is a significant number of unreported cases of domestic violence, and the "silence" of family members can lead to immeasurable consequences.

According to Article 197, paragraph 1 of the Family Law (2005), "domestic violence is behavior by which one family member endangers the physical integrity, mental health or tranquility of another family member". The same definition is used in the publication by Žarković et al. (2012, p. 5). Domestic violence can also be defined as "a form of violence committed within the household, kinship or partnership, regardless of whether the persons live together" (Petrušić \& Konstatinović Vilić, 2010, p. 138). According to Jovanović and Lukić (2003), "although research on domestic violence shows that it is a phenomenon whose intensity increases over time and which, as a rule, changes forms, criminal law, and criminological definitions recognize violence only as physical violence and/or threat of physical violence. However, the practice sees the constant of domestic violence as all other types of coercion (threats, coercion and/or use of force) aimed at controlling the victim's behavior, establishing power over them, or abusing their trust "(p. 7).

It can be said that there is no one universal definition of domestic violence. However, according to Opsenica Kostić and associates (2016), "as a common denominator of different definitions, we could consider forms of violence that 
should be sanctioned, and these are physical, psychological, economic and sexual violence" (p. 132). It should also be emphasized that in practice female victims of domestic violence, often "do not separate the physical from the sexual abuse. Thus, the results of the research of the Group for Women's Human Rights of the European Movement in Serbia show that sexual abuse was the most common accompaniment of particularly severe or most severe forms of physical violence" (Lukić \& Jovanović, 2001, p. 139). Thus, the notion of "domestic violence" and "domestic violence against women" can be interpreted within a social construct, changed over time and reflecting power dinamics within a relationship" (Opsenica Kostić et. al., 2016, p. 139).

According to Petrušić and Konstatinović Vilić (2010), "domestic violence occurs in several forms: marriage violence, partner violence, violence against members of the joint household, violence against children" (p. 138).

The following table shows how domestic violence manifests itself, from which it can be concluded that this phenomenon can manifest in several ways.

Table 1. Forms of manifestation of domestic violence

\begin{tabular}{|l|l|}
\hline Forms of domestic violenc & Description of manifestation forms \\
\hline Physical Violence & $\begin{array}{l}\text { It encompasses inflicting or attempting to inflict bodily } \\
\text { injury (hitting with hands, feet, or hard objects, pulling } \\
\text { hair, squeezing the neck, pushing, throwing on the } \\
\text { ground, stabbing with a knife or other sharp object, etc.) }\end{array}$ \\
\hline Sexual Violence & $\begin{array}{l}\text { It encompasses forcing or inducing sexual intercourse } \\
\text { (rape, incest, unwanted touching, coercion into } \\
\text { certain sexual acts or pornography, humiliating sexual } \\
\text { intercourse, etc.) }\end{array}$ \\
\hline Psychological Violence & $\begin{array}{l}\text { It encompasses emotional threats or injury (threats, } \\
\text { causing fear, restricting freedom of movement or } \\
\text { communication with third parties, insulting, calling } \\
\text { derogatory names, ridicule, humiliation, etc.). }\end{array}$ \\
\hline Economic Violence & $\begin{array}{l}\text { It implies economic subordination of the victim to the } \\
\text { perpetrator (unequal access to common funds, denial, control } \\
\text { of access to money, prevention of employment or education } \\
\text { and professional advancement, denial of property rights, etc.). }\end{array}$ \\
\hline
\end{tabular}

Source: Žarković, M., Šurlan, T., Kiurski, J., Matić, M. \& Josimović, S. (2012). Ka boljoj zaštiti žrtava nasilja u porodici - odgovor pravosuđa [Towards better protection of victims of domestic violence - the response of the judiciary]. Beograd: Udruženje javnih tužilaca i zamenika javnih tužilaca Srbije, p. 6. 
Forms of domestic violence can in theory be divided into passive and active violence against women, which is presented in the following table.

Tabl 2. The theoretical framework of domestic violence against women

\begin{tabular}{|c|c|c|}
\hline \multirow{4}{*}{$\begin{array}{l}\text { Forms of } \\
\text { domestic } \\
\text { violence } \\
\text { against } \\
\text { women }\end{array}$} & \multirow{3}{*}{$\begin{array}{l}\text { Passive } \\
\text { violence }\end{array}$} & $\begin{array}{l}\text { Undermining the physical status of women includes } \\
\text { violence against health: neglect of the importance of } \\
\text { pregnancy and childbirth, mortality of mothers and } \\
\text { female newborns. }\end{array}$ \\
\hline & & $\begin{array}{l}\text { Undermining the psychological position of women, } \\
\text { which includes four subgroups: } \\
\text { - emotional violence: the imperative of caring for } \\
\text { another, and at the same time not caring about oneself, } \\
\text { self-hatred of women, glorification of motherhood; } \\
\text { - sexual violence: reduction of female sexuality } \\
\text { exclusively to the reproductive sphere, the great } \\
\text { importance of marriage, abduction and trafficking in } \\
\text { women, imperative of female innocence, fidelity and } \\
\text { fertility; } \\
\text { - motivational violence: inability to make decisions, } \\
\text { prohibition in the behavior of girls and women, ritual } \\
\text { humiliation of women; } \\
\text { - cognitive violence: illiteracy of women, poorer } \\
\text { education of women, the transmission of bad ideas } \\
\text { about themselves to future female generations. }\end{array}$ \\
\hline & & $\begin{array}{l}\text { Undermining the economic position of women: cyclical } \\
\text { nature of work obligations, discontinuity of working } \\
\text { hours, forced labor, care for children, the sick and the } \\
\text { elderly, unpaid work. }\end{array}$ \\
\hline & $\begin{array}{l}\text { Active } \\
\text { violence }\end{array}$ & $\begin{array}{l}\text { Active violence against women occurs when perpetrators } \\
\text { of violence switch to, based on their social position, or } \\
\text { due to physical superiority in family relationships, the } \\
\text { direct use of violence. These include slapping, shooting, } \\
\text { hitting, using weapons, and more. }\end{array}$ \\
\hline
\end{tabular}

Source: Popadić, D. \& Bogavac, Lj. (2003). Tehnike intervjuisanja dece $i$ žena koji su preživeli seksualno zlostavljanje [Interview techniques for children and women who have survived sexual abuse]. Beograd: Incest trauma centar, p. 19.

In addition to the above-mentioned, the theory recognizes several forms of domestic violence, which we'll mention here. These are the following forms of domestic violence: 
1. Violence in partnerships - Partnership violence against women is "violence committed by current and former partners, regardless of whether they are married or unmarried, and whether they live together or in separate households" (Opsenica Kostić, et. al., 2016, p. 139). It differs from other forms of domestic violence "in that it is a relationship of seemingly equal standing, as opposed to the children and parents, adults and adult children and their parents "(Ajduković, 2000, p. 55).

2. Marital violence - The term "marital violence" means the "victimization" of a person with whom the abuser had or has established a marital union. It includes both violence against women and violence against men "(Stanković, 2014, p. 15). Domestic violence is also defined as "a series of behaviors used by a person to gain or retain power and control over a spouse. Such behaviors can happen once, in a longer period, continuously, or from time to time " (Balić et al., 2001, p. 76).

3. Violence in cohabitation - Violence in cohabitation could be defined as "physical, psychological, economic and sexual abuse or coercion by a man against a woman, and a woman against a man, or between persons of the same sex, between whom there is a community of life established under the law" (Stanković, 2014, p. 19).

4. Violence in same-sex relationships - Violence in same-sex relationships can be defined as "physical, psychological, emotional, sexual and economic abuse by a person of one sex towards a person of the same sex, who is in a relationship" (Stanković, 2014, p. 19).

5. Domestic violence against children - Under the term domestic violence against children, the National Strategy for Prevention and Protection of Children from Violence (2020) uses the definition of the World Health Organization according to which "child abuse or abuse includes all forms of physical or emotional abuse, sexual abuse, neglect or negligence. conduct, as well as commercial or other exploitation, leading to actual or potential impairment of the child's health, survival, development, or dignity within a relationship involving responsibility, trust, or power. According to Milosavljević Đukić and Tanković (2018), "children may be exposed to the risk of direct and indirect victimization by violence within the family environment. This means that a child can be victimized directly, when he or she is a direct victim of violence, or 
indirectly when he or she witnesses violence against other family members" (p. 69).

If we analyze the causes of domestic violence, we can say that the characteristics of the "social system in which we find ourselves, a transition period characterized by, among other things, a high degree of instability and existential insecurity." (Matijašević Obradović, Stefanovič, 2017, p. 16), can lead to different possibilities of violent behavior in one family, and consequently, the causes of domestic violence can be numerous and very pronounced.

According to Nikolić Ristanović (2003), transition-related factors influencing domestic violence can be "classified into two groups: factors influencing exposure to domestic violence and factors preventing victims from leaving the perpetrator"(p. 6). Nikolić Ristanović (2003) further points out that the factors "influencing the increased vulnerability, especially of women, to domestic violence are: 1. Oppression of men and marginalized masculinity (crisis of masculinity) in the public sphere as opposed to strengthening traditional expectations and sides of the man under which he should act in the private sphere (power/impotence dichotomy); 2. Deterioration of the socio-economic status of men; 3 . The transition of women to a better socio-economic status and the widening gap between the socio-economic status of men and women/partners; 4 . Crisis of male and crisis of generational identity as a factor of violence of adult dependent sons; 5 . Low/declining (under the influence of social stress) communication skills of men and women" (p. 6).

It is interesting to mention that, according to research, how women victims of violence, most often react in situations where they are exposed to violence. According to Čudina Obradović \& Obradović (2006), these are most often the following reactions: "denial of the problem (they believe that the problem does not exist, so no solution should be sought); reshaping the problem (expect the situation to get better because of the children, love, etc.); self-accusation and seeking justification (they suffer violence in everyday life and try to justify it); self-control and control of others (they adhere to the attitude that the abuser is "provoked" and carefully choose actions and words in the communication); seeking social support (they seek support in the current situation, most often from friends and relatives, while it is difficult to seek help from a professional service); active problem solving (they have a hidden solution in case the situation becomes too dangerous)" (p. 486). 


\section{Protection from domestic violence in the sense of the Family Law}

Family Law (2005) "regulates: marriage and marital relations, extramarital relations, child-parent relations, adoption, foster care, guardianship, alimony, family property relations, protection from domestic violence, procedures related to family relations and personal name" (Article 1).

The ninth part of the Family Law (2005) regulates the area of protection against domestic violence. Thus, in the sense of Article 197, paragraph 2, domestic violence, in the sense of the definition given in paragraph 1, "shall be considered in particular: infliction or attempted infliction of bodily injury; causing fear by threatening to kill or inflict bodily harm on a family member or a person close to them; coercion into sexual intercourse; inducing sexual intercourse or sexual intercourse with a person under the age of 14 or an incapacitated person; restriction of freedom of movement or communication with third parties; insult, like any other insolent, reckless and malicious behavior."

The same article, in paragraph 3, stipulates that "family members are considered to be: spouses or ex-spouses; children, parents and other blood relatives, and persons who are in-laws or adoptive relatives, persons bound by the foster care; persons living or who have lived in the same family household; extramarital partners or former extramarital partners; persons who have been or are still in an emotional or sexual relationship with each other, or who have a child together or the child is about to be born, even though they have never lived in the same family household".

Article 3 of the Family Law (2005) stipulates that "marriage is a legally regulated union of life between a woman and a man. It can be concluded only with the free consent of future spouses. Spouses are equal." In addition to marriage, the law also recognizes the extramarital union, "as a more permanent union of life between a woman and a man, between which there are no marital obstacles - extramarital partners." Extramarital partners have the rights and duties of a spouse under the conditions determined by law" (Article 4).

Article 10 of the Family Law (2005) stipulates that "domestic violence is prohibited". In doing so, everyone has, by law, the right to be protected from domestic violence.

Pursuant to Article 198, paragraph 1, of the Family Law (2005), "against a family member who commits violence, the court may order one or more measures of protection against domestic violence, which temporarily prohibits or restricts personal relations with another family member." 
Measures of protection against domestic violence, which are given in paragraph 2 of the same article, include: "1. issuing an eviction order from the family apartment or house, regardless of the right of ownership or lease of real estate; 2. issuing an order for moving into a family apartment or house, regardless of the right of ownership or lease of real estate; 3 . a restraining order on approaching a family member at a certain distance; 4 . A restraining order on access to the institution around the place of residence or place of work of a family member; 5. Prohibition of further harassment of a family member."

The measure of protection against domestic violence, in accordance with paragraph 3 of Article 198 of the Family Law (2005) may last for a maximum of one year. Article 199 stipulates that a measure "may be extended until the reasons for which the measure was imposed ceases to exist, and may cease before the expiry of the duration if the reasons for which the measure was imposed cease to exist".

\section{Protection from domestic violence in the sense of the Law on Social Protection}

Article 2 of the Law on Social Protection (2011) stipulates that social protection is "organized social activity of public interest whose goal is to provide assistance and empowerment for an independent and productive life in the society of individuals and families, as well as preventing and eliminating the consequences of social exclusion.". Article 3 regulates the goals of social protection. The goals of social protection in the part concerning protection against domestic violence are given in points 4) and 5) and refer to "preservation and improvement of family relations, as well as promotion of family, gender and intergenerational solidarity", as well as to "prevention abuse, neglect or exploitation, or remedy of their consequences."

Article 4 of the Law on Social Protection (2011) stipulates that "every individual and family in need of social assistance and support in order to overcome social and life difficulties and create conditions for meeting basic life needs have the right to social protection, under the law." According to Article 14, "established rights and provision of social protection services" are exercised by the Social Services Centre.

In accordance with Article 41, it is determined that the goals of social protection are "achieved by providing services to beneficiaries". As a special group of social protection beneficiaries, Article 41, paragraph 2, item 6 defines a group of persons for whom "there is a danger of becoming a victim or if they are a victim of abuse, neglect, violence, and exploitation, or if their physical, mental or 
emotional well-being and development are endangered by the actions or omissions of a parent, guardian or another person who directly cares for them".

Article 120 of the Law on Social Protection (2011) stipulates that the Social Services Centre: "1) assesses the needs and strengths of beneficiaries and risks they are exposed to and plans the provision of social protection services accordingly; 2) carries out procedures and decides on the rights to material benefits and the use of social protection services; 3 ) takes prescribed measures, initiates and participates in court and other proceedings; 4) keeps the prescribed records and take care of keeping the beneficiaries documentation."

In addition to the above-mentioned tasks of the Social Services Center, in terms of domestic violence, has "other tasks" regulated in Article 121 which are also considered important. In the field of social protection on the territory of the local self-government unit for which it is established, the Center initiates and develops preventive and other programs that contribute to the prevention and suppression of social problems and performs other tasks in the field of social protection, in accordance with law and other regulations.

Uncovering of individual cases of domestic violence "experts of the Social Services Center - guardianship authority, happens directly in the performance of their scope of work closely related to social and family protection, and indirectly, through reports from other government agencies, victims, relatives, and citizens" (Special Protocol on the Procedure of Social Services Center - Guardianship Bodies in Cases of Domestic Violence and Women in Partnerships, 2013, pp. 20-21).

The Social Services Center - guardianship authority is obligated to "provide directly and in cooperation with other services and bodies in the local community the service of immediate intervention and help for victims of domestic violence, when it is necessary to take measures to ensure safety and health, or when failure to take urgent measures and services within the competence of the Social Services Center - guardianship authority can endanger the life, health, and development of the victim of violence in the family or a person in need of protection. Immediate intervention must be realized immediately or no later than within 24 hours from the moment of learning about the case" (Special Protocol on the Procedure of Social Services Center - Guardianship Bodies in Cases of Domestic Violence and Women in Partnership, 2013, p. 23).

Regarding the powers that the Social Services Center has in its work, it is important to mention the Rulebook on the organization, norms, and standards of work of Social Services Center (2008). Thus, among others, the provision of Article 4 of this Ordinance (2008) states the public powers of the Center regarding protection against domestic violence, which: "conducts the procedure 
of mediation in family relations (conciliation and settlement); submits the finding and expert opinion, at the request of the court, in litigations in which decisions are made on the protection of the rights of the child or the exercise or deprivation of parental rights; submits, at the request of the court, an opinion on the expediency of the measure of protection against domestic violence requested by another authorized prosecutor; assists in obtaining the necessary evidence to the court before which the proceedings in the dispute for protection against domestic violence are being conducted; conducts the procedure of assessing the general suitability of foster parents, adoptive parents, and guardians, etc."

The aforementioned powers of the Center should be understood in terms of giving broader prerogatives that seek to complement the area of domestic violence regulation.

\section{Conclusion}

With global social changes, there are changes in every special sphere of society, even in the family itself. Primarily, the family is losing more and more of its importance. The information society and the high mobility of citizens put a lot of choices in front of people. Among these choices, the family is becoming less and less prioritized on the list of priorities.

Domestic violence is a complex and multidisciplinary problem.

In addition to the concept, characteristics, manifestation forms, and causes of domestic violence, the paper presents the provisions of the Family Law and the Law on Social Protection, in the part concerning protection from domestic violence, emphasizing the role of the Social Services Center and powers which this body has in terms of protection from domestic violence. However, it is important to mention that good legislation is often overcome by some life situations, so it is necessary to constantly deal with issues such as domestic violence, and "keep up" with criminological tendencies in the dynamics of manifestation and development of this type of problem.

It can also be said that the number of reported cases of domestic violence is increasing every year. However, having in mind that this area is still recognizable by the "dark figure", it is concluded that a large number of violent acts in marital and partnership relations remains undiscovered, despite all efforts to change such tendencies.

In the light of all of the above, it is necessary to emphasize adequate education, good coordination of institutions, but also influencing the social 
consciousness of people that denying the perceived problem of domestic violence leads nowhere. Also, good coordination of institutions has proven to be extremely important in the effective solution of problems, primarily referring to the cooperation of the police, the Social Services Center, and the Judiciary system in sanctioning and preventing domestic violence.

\section{Stamenković Goran}

Stečajni upravnik, doktor pravnih nauka, Odžaci, Srbija

\section{ZAŠTITA OD NASILJA U PORODICI U SMISLU PORODIČNOG ZAKONA I ZAKONA O SOCIJALNOJ ZAŠTITI}

REZIME: Nasilje u porodici je složen, multidisciplinaran problem, iako na prvi pogled deluje kao vrlo jasna, određena, krajnje očigledna i prepoznatljiva pojava. Pored pojma, karakteristika, načina ispoljavanja i uzroka nasilja u porodici, u radu su predstavljene odredbe Porodičnog zakona i Zakona o socijalnoj zaštititi, kao i uloga i ovlašćenja Centra za socijalni rad u pogledu zaštite od nasilja u porodici. Tzv. „tamna brojka“ u ovoj oblasti ukazuje da postoji znatan broj neprijavljenih slučajeva nasilja u porodici, a „ćutanje“ članova porodice može dovesti do nemerljivih posledica. Zato je potrebno staviti naglasak na adekvatnu edukaciju, dobru kordinaciju institucija ali i uticanje na društvenu svest ljudi da negiranje uočenog problema nasilja u porodici ne vodi nikuda.

Ključne reči: nasilje u porodici, Porodični zakon, Zakon o socijalnoj zaštiti, Centar za socijalni rad.

\section{References}

1. Ajduković, D. (2000). Nasilje nad ženom u obitelji [Domestic violence against women]. Zagreb: DPP

2. Balić S., Divanović D., \& Ricijaš N. (2001). Nasilje i ubojstvo intimnih partnera [Violence and murder of intimate partners]. Kriminologija i socijalna integracija, 9 (1-2), pp. 71-84 
3. Čudina Obradović, M. \& Obradović, J. (2006). Psihologija braka i obitelji [Psychology of Marriage and Family]. Zagreb: Golden marketing - Tehnička knjiga.

4. Dragojlović, J., \& Matijašević Obradović, J. (2019). Krivičnopravni aspekti nasilja u porodici u Srbiji [Criminal Aspects of Violence in Family in Serbia]. Socijalna misao, 26 (1), pp. 55-66

5. Ignjatović, T. (2011). Nasilje prema ženama u intimnom partnerskom odnosu: model koordiniranog odgovora zajednice [Violence against women in intimate partnerships: a model of coordinated community response]. Beograd: Rekonstrukcija Ženski fond

6. Jovanović, S., \& Lukić, M. (2003). Nasilje u porodici: nova inkriminacija [Domestic violence: a new incrimination]. Beograd: Autonomni ženski centar, Ministarstvo za socijalna pitanja

7. Konstantinović Vilić, S., \& Petrušić, N. (2003). Krivično delo nasilja u porodici: pravna praksa na teritoriji Niša [Criminal offense of Domestic violence: legal practice on the territory of Nis]. Temida, 6 (2), pp. 27-36

8. Lukić, M., \& Jovanović, S. (2001). Drugo je porodica: Nasilje u porodici - nasilje u prisustvu vlasti [The second is the family: Domestic violence - violence in the presence of the authorities]. Beograd: Institut za kriminološka i sociološka istraživanja

9. Matijašević Obradović, J., \& Stefanović, N. (2017). Nasilje u porodici u svetlu Porodičnog zakona, Krivičnog zakonika i Zakona o sprečavanju nasilja u porodici [Domestic violence in the light of the Family Code, the Criminal Code and the Law on Prevention of Domestic Violence]. Pravo - teorija i praksa, 34 (4-6), pp. 13-28

10. Milosavljević Đukić, I., \& Tankosić, B. (2018). Porodično nasilje: karakteristike nasilja nad decom i posledice na razvoj dece [Domestic violence: characteristics of violence against children and consequences on children's development]. Vojno delo, 70 (5), pp. 67-81

11. Nikolić Ristanović, V. (2003). Krivično delo nasilje u porodici u društvenom kontekstu i pravnom sistemu Srbije i Crne Gore [The crime of Domestic violence in the social context and legal system of Serbia and Montenegro]. Temida, 6 (2), pp. 5-10

12. Nikolić Ristanović, V. (2002). Porodično nasilje u Srbiji [Domestic violence in Serbia]. Beograd: Viktimološko društvo Srbije

13. Njagulović, J. (2012). Nasilje u porodici: tri segmenta pravne zaštite u domaćem zakonodavstvu [Domestic violence: three segments of legal protection in domestic legislation]. Zbornik radova Pravnog fakulteta $u$ Nišu, 51 (62), pp. 593-603 
14. Opsenica Kostić, J., Todorović, J., \& Janković, I. (2016). Izazovi savremene porodice [Challenges of the modern family]. Niš: Univerzitet u Nišu

15. Petrušić, N., Žunić, N. \& Vilić, V. (2018). Krivično delo nasilja u porodici u sudskoj praksi: nove tendencije i izazovi [The crime of domestic violence in court practice: new tendencies and challenges]. Beograd: Organizacija za evropsku bezbednost i saradnju - Misija u Srbiji

16. Petrušić, N., \& Konstantinović Vilić, S. (2010). Porodično pravna zaštita od nasilja u porodici u pravosudnoj praksi Srbije [Protection of Family Law from domestic violence in Serbian judicial practice]. Beograd: Autonomni ženski centar

17. Porodični zakon [Family law]. Službeni glasnik RS, br. 18/05, 72/11 - dr. zakon i $6 / 15$

18. Popadić, D., \& Bogavac, Lj. (2003). Tehnike intervjuisanja dece i žena koji su preživeli seksualno zlostavljanje [Interview techniques for children and women who have survived sexual abuse]. Beograd: Incest trauma centar

19. Poseban protokol o postupanju Centara za socijalni rad - organa starateljstva u slučajevima nasilja u porodici $i$ ženama u partnerskim odnosima [Special Protocol on the Conduct of Centers for Social Work - Guardianship Bodies in Cases of Domestic Violence and Women in Partnerships] (2013). Beograd: Ministarstvo rada, zapošljavanja i socijalne politike

20. Pravilnik o organizaciji, normativima i standardima rada centra za socijalni rad [Rulebook on the organization, norms and standards of work of the Center for Social Work]. Službeni glasnik RS, br. 59/08, 37/10, 39/11 - dr. pravilnik i 1/12 - dr. pravilnik

21. Stanković, M. (2014). Nasilje u braku i partnerskim odnosima: master rad [Violence in Marriage and Partnerships: master thesis]. Niš: Pravni fakultet Univerziteta u Nišu

22. Strategija za prevenciju i zaštitu dece od nasilja za period od 2020. do 2023. godine [Strategy for Prevention and Protection of Children from Violence for the period from 2020 to 2023]. Službeni glasnik RS, br. 80/20

23. Zakon o socijalnoj zaštiti [Law on Social Protection]. Službeni glasnik $R S$, br. $24 / 11$

24. Žarković, M., Šurlan, T., Kiurski, J., Matić, M. \& Josimović, S. (2012). Ka boljoj zaštiti žrtava nasilja u porodici: odgovor pravosuđa [Towards better protection of victims of Domestic violence: the response of the judiciary]. Beograd: Udruženje javnih tužilaca i zamenika javnih tužilaca Srbije 